\title{
Effect of Diode Laser on Human Cytomegalovirus and Epstein - Barr Virus in Chronic Periodontitis Patients - A Quantitative Real-Time Polymerase Chain Reaction Study
}

\author{
Sandeep. S. Prabhu, Krishna Kripal, Deepthi. R, Rakesh. M.P, Manjunath. S. M, and Shanmugapriya. P. A
}

\begin{abstract}
Background and aims: Studies have investigated the occurrence of Human cytomegalovirus (HCMV) and Epstein Barr Virus (EBV) in samples of both chronic and aggressive periodontitis lesions and their role in the pathogenesis of the disease have been suggested. It is important to determine the role and presence of these viruses in chronic generalized periodontitis patients after Scaling and root planing (SRP) alone and in conjunction with diode laser application. Thus the aim of the present study was to determine the prevalence of human cytomegalovirus (HCMV), Epstein-Barr virus(EBV) in gingival crevicular fluid (GCF) samples obtained from chronic generalised periodontitis patients.
\end{abstract}

Materials (Subjects) and Methods: A total of 30 patients were included in the study based on the inclusion and exclusion criteria as follows: Group I - 15 chronic generalized periodontitis patients who received treatment with scaling and root planing. Group II - 15 chronic generalized periodontitis patients who received treatment with scaling and root planing and Diode laser. In each patient GCF samples were collected at baseline, 7 days and 21 days after treatment. Clinical parameters like gingival index, probing pocket depth and clinical attachment level were recorded and as GCF samples collected.

Results: Correlation between quantification of EBV values with clinical parameters such as gingival index, probing pocket depth and clinical attachment loss in two groups showed statistical significance $(P<0.001)$. Relative quantification of EBV was statistically significant, whereas HCMV was significantly absent. The mean values of GI, PPD and CAL parameters at different time interval was found to be statistically significant in both group $(P<0.001)$

Conclusions: Only EBV was detected more frequently in patients with CGP, but HCMV was not detected with similar frequency in the groups studied. We also found that group with application of diode laser showed statistical significant results.

Index Terms - Chronic generalised periodontitis, Diode laser, Epstein - Barr virus, Gingival crevicular fluid, Human cytomegalovirus, PCR, Scaling and Root planning.

Sandeep. S. Prabhu, Department of Periodontology, Al- Badar Dental College and Hospital, Gulbarga, India.

Krishna Kripal, Department of Periodontology, Rajarajeswari Dental College and Hospital, Bangalore, India.

(email: kripalkrishna@yahoo.com)

Deepthi. R, Department of Periodontology, Rajarajeswari Dental College and Hospital, Bangalore, India.

(email: deepthir588@,gmail.com)

Rakesh. M. P, Rakesh Dental Clinic, Bellary, India

Manjunath. S. M. , Department of Periodontology, Rajarajeswari Dental College and Hospital, Bangalore, India.

Shanmugapriya. P, Department of Periodontology, Rajarajeswari Dental College and Hospital, Bangalore, India.

\section{INTRODUCTION}

Periodontitis is a disease attributable to multiple infectious agents and interconnected cellular and humoral host immune responses. However; it has been difficult to unravel the precise role of various putative pathogens and host responses in the pathogenesis of periodontitis. It is not understood why, in hosts with comparable levels of risk factors, some periodontal infections result in loss of periodontal attachment and alveolar bone, while other infections are limited to inflammation of the gingiva with little or no discernible clinical consequences. Also, many periodontitis patients do not show a remarkable level of classical risk factors [1], [2].

Detection and quantification of periodontopathic bacterial species are useful for identifying subjects at elevated risk of periodontitis, but do not consistently predict clinical outcome. These uncertainties have galvanized efforts to find additional etiologic factors for periodontitis. Even though specific infectious agents are of key importance in the development of periodontitis, it is unlikely that a single agent or even a small group of pathogens are the sole cause or modulator of this heterogeneous disease [3].

Since the mid-1990s, herpes viruses have emerged as putative pathogens in various types of periodontal disease. $4,5,6)$ In particular, human cytomegalovirus (HCMV) and Epstein-Barr virus (EBV) seem to play important roles in the etiopathogenesis of severe types of periodontitis.

Genomes of the two herpesviruses occur at high frequency in disease progressive as seen in progressive periodontitis in adults, localized and generalized aggressive (juvenile) periodontitis, HIV-associated periodontitis, acute necrotizing ulcerative gingivitis, periodontal abscesses, and some rare types of advanced periodontitis associated with medical disorders.7,8) HCMV infects periodontal monocytes/ macrophages and T-lymphocytes, and EBV infects periodontal B-lymphocytes [9]

According to Slots [10] periodontal destruction may be associated with the coexistence of periodontal herpes viruses, especially human cytomegalovirus (HCMV) and Epstein-Barr virus (EBV), periodontopathogenic bacteria, and the local impaired host immune response. AgP sites presenting HCMV, EBV-1, or herpes simplex virus (HSV) had a higher occurrence of $P$. gingivalis and $D$. pneumosintes than sites without the viruses [11]. Also, Aggressive periodontitis (AgP) sites infected with active HCMV harbored more A. actinomycetemcomitans than sites with latent HCMV infection [12]. 
Herpesvirus-infected inflammatory cells elicit tissuedestroying cytokines and may exert diminished ability to defend against bacterial challenge [13]. Herpesvirusassociated periodontal sites also tend to harbor elevated levels of periodontopathic bacteria, including Porphyromonas gingivalis, Tannerella forsythia, Dialister pneumosintes / Dialister invisus, Prevotella intermedia, Prevotella nigrescens, Treponema denticola, Campylobacter rectus and Actinobacillus actinomycetemcomitans [14], [15]. Transcripts of HCMV and EBV have been identified in the great majority of symptomatic periapical lesions as well. In the light of the close statistical relationship between herpesviruses and periodontitis, it is reasonable to surmise that some cases of the disease have a herpesviral component.

Saygun et al. reported that HCMV, EBV-1, and HSV-1 were positively associated with $\mathrm{P}$. gingivalis, $\mathrm{P}$. intermedia, T. forsythia, and C. rectus but not with $A$. actinomycetemcomitans in young adults with advanced periodontitis [16].

The herpesviral infection can stimulate the release of cytokines and chemokines from inflammatory and noninflammatory cells and impair the periodontal immune defense, resulting in more virulent resident bacteria [13] Periodontal bacterial infection elicits an inflammatory response in periodontal tissues, resulting in dense infiltration of the T- lymphocytes, B lymphocytes, and macrophages [13].

However, from our systematic literature review, there is limited data available on the effect of diode laser treatment on the reduction of viral load in South Indian population. Hence this study has been undertaken to evaluate the effect of diode laser on the prevalence of HCMV \& EBV in chronic periodontitis using real time polymerase chain reaction technique. Thus the aim of the present study was to determine the prevalence of human cytomegalovirus (HCMV), Epstein-Barr virus (EBV) in gingival crevicular fluid (GCF) samples obtained from chronic periodontitis patients. In addition, the effect of diode laser in periodontal treatment was to examine the long-term effect of diode laser therapy on periodontal pockets with regard to the improvement of periodontal condition.

\section{MATERIALS AND METHODS}

\section{A. Patients}

Patients who visited outpatient department of Periodontology, Rajarajeswari Dental College and Hospital, Bangalore were selected for this study between June 2014 and August 2015. Inclusion criteria were: a) Patient having a minimum of 20 teeth, b) Sites having a probing depth $=5 \mathrm{~mm}, \mathrm{c})$ Sites having clinical attachment loss $=3 \mathrm{~mm}, \mathrm{~d}$ ) Radiographic evidence of alveolar bone loss. Exclusion criteria were: a) Patients with history of systemic diseases affecting the periodontium, b) Smokers, c) Patients on any medication taken within the last 6 months which may alter the periodontal status, d) Pregnant and lactating mothers, e) Patients who have undergone periodontal treatment within a period of 1 year.

The study protocol was approved by the Research Ethics Committee of Rajarajeswari Dental college and hospital. All patients were informed about the study and gave written informed consent to participate.

All the subjects underwent a full mouth periodontal probing and charting and were screened for suitability. A proforma was designed for the present study so as to have a systematic and methodical recording of all the observations and information. The relevant data were recorded in the proforma. Chronic periodontitis patients were diagnosed based on criteria discussed at the 1999 International workshop of periodontology.

A total of 30 patients included in the study and were grouped as follows:

Group I - 15 Chronic generalized Periodontitis patients were treated with scaling and root planing alone.

Group II - 15 chronic generalized periodontitis patients were treated with scaling and root planing and Diode laser.

\section{B. Clinical parameters}

All baseline and follow up, intrasurgical measurements were carried out by the same examiner. Measurements were made using a graduated William's periodontal probe and were rounded off to the nearest millimeter

Gingival index (Loe H \& Silness P, 1963): Gingival index (GI) was assessed using a mouth mirror and probe. The teeth and gingiva were dried lightly with cotton rolls. The tissues surrounding each tooth were divided into 4 gingival scoring units: distal-facial papilla, facial margin, mesial-facial papilla and the entire lingual gingival margin. Each of the four gingival units was assessed.

Probing Pocket Depth (PPD): The graduated William's periodontal probe was inserted parallel to the long axis of the tooth to measure the pocket depth at 3 buccal (mesiobuccal, midbuccal and distobuccal) and 3 lingual (mesiolingual, midlingual and distolingual) sites for all maxillary and mandibular teeth. The pocket depth was evaluated by determining the distance between crest of the gingival margin to the base of the pocket. Mean pocket depth for a subject was calculated by adding measured pocket depth around all the teeth and divided by number of teeth examined.

Clinical attachment level (CAL): CAL was measured as the distance from the cemento-enamel junction (CEJ) to the base of the gingival sulcus using the periodontal probe.

Mean CAL for a subject was calculated by adding measured pocket depth around all the teeth and divided by number of teeth examined.

GI, PPD and CAL were recorded at baseline before any non-surgical periodontal therapy started and also 7 and 21 days after the therapy.

\section{SAMPLE COLLECTION}

All the subjects were examined and screened for the study. Patients were informed and written consent was obtained. GCF was collected using sterile paper point by inserting into deep periodontal pocket without applying pressure. GCF sample was collected 24 hours after periodontal examination in order to avoid blood contamination of samples. All samples were collected from the deepest periodontal pocket.

The sample was isolated from saliva with cotton rolls and gently air dried. The supragingival plaque was removed by 
sterile cotton pellets. Two paper points were inserted in each periodontal pocket until a mild resistance for 30 seconds. Paper point of ISO \# 40 was used. Paper points contaminated with blood were not used in the analysis. These paper points were placed in sterile plastic tubes containing TE buffer and stored at $-70^{\circ} \mathrm{C}$ until further analysis.

In Group 1, each patient received scaling and root planning using Gracey curettes until a hard, smooth and calculus-free root surface was achieved.

In Group 2, Diode laser ((SIROLaser ${ }^{\circledR}$, Sirona, Bensheim, Germany) $980 \mathrm{~nm}$ at a power output of $2.5 \mathrm{~W}$ in pulsed mode $(30 \mathrm{~Hz}$, pulse duration $60 \mathrm{~s}$ ) was used as an adjunctive to scaling and root planing. The optic fiber of $400 \mu \mathrm{m}$ was moved from the coronal to apical side of the pocket in parallel paths with an inclination of approximately $20^{\circ}$. Each pocket of the test group was lased for 30 s twice, with a $60 \mathrm{~s}$ interval.

\section{TREATMENT PROCEDURE}

All patients received full mouth disinfection i.e. scaling and root planing along with chlorhexidine applications within 24 hours.

\section{A. Scaling and root planing:}

Scaling and root planning was performed by the same investigator in both the groups using EMS scaler and standard periodontal curettes. Local anesthesia was used whenever needed. The time needed for the procedure was approximately 1 hour. Recall examinations were done at 7 th and 21 st day after the treatment for assessment of clinical parameters and collection of GCF samples for viral analysis.

\section{B. For sample storage: $-70^{\circ} \mathrm{C}$ refrigerator (New \\ Brunswick Scientific)}

\section{DNA extraction}

DNA extraction from the GCF samples was done using highly purified Invitrogen DNA isolation kit (Purelink ${ }^{\mathrm{TM}}$ DNA extraction kit) Applied Biosystems, India. Before DNA extraction, the paper point was completely submerged in TE buffer and kept in room temperature for $2 \mathrm{hrs}$.

1. The vials containing TE buffer was centrifuged for 3000 rpm for 2 minutes.

2. About $200 \mu \mathrm{l}$ of the solution was transferred into sterile micro centrifuged tube.

3. Then $20 \mu \mathrm{l}$ of proteinase $\mathrm{K}$ was added to a sterile microcentrifuge tube.

4. The tubes were kept at $55^{\circ} \mathrm{C}$ for 2 hours in water bath with occasion vortexing unless and untill its completed.

5. $20 \mu \mathrm{l}$ of RNAse-A was added to the lysate and mixed well by briefly vortexing and was incubated at room temperature for 2 minutes.

6. $200 \mu \mathrm{l}$ of Purelink ${ }^{\mathrm{TM}}$ Genomic Lysis/Binding buffer was added and mixed well by vortexing to obtain a homogenous solution.

7. $200 \mu \mathrm{l}$ of $96-100 \%$ ethanol was then added and mixed well by vortexing for 5 seconds to obtain a homogeneous solution and was subjected to purification protocol immediately.

\section{DNA Purification}

1. The purification procedure is designed for purifying genomic DNA using a spin- column based centrifugation procedure on a total time of 10-15 minutes.

1. Purelink TM spin-column was removed from the package and placed in a clean collection tube.

2. The entire lysate prepared with Purelink ${ }^{\mathrm{TM}}$ Genomic Lysis/Binding buffer and ethanol was added to the spincolumn.

3. The column was centrifuged at $10000 \mathrm{rpm}$ for 1 minute at room temperature.

4. The spin-column was then placed into a clean Purelink ${ }^{\mathrm{TM}}$ collection tube supplied with the kit.

5. $500 \mu \mathrm{l}$ of "Wash Buffer-1" prepared with ethanol was added to the column.

6. The column was centrifuged at maximum speed for 3 minutes at room temperature. The collection tube was discarded.

7. The spin-column was placed in a sterile $1.5 \mathrm{ml}$ microcentrifuge tube.

8. $40 \mu \mathrm{l}$ of Purelink ${ }^{\mathrm{TM}}$ genomic elution buffer was added to the column and incubated at room temperature for 1 minute.

9. The column was then centrifuged at maximum speed for 1 minute at room temperature thus obtaining purified genomic DNA in the tube.

10. Purified DNA was stored at $-20^{\circ} \mathrm{C}$ until further processing.

\section{E. Primers and probes}

Custom TaqMan inventoried assay for pathogen identification was used to identify HCMV. The details are as follows and available at www.lifetechnologies.com/order/genomedatabase/details/gene expression/Pa03453400s1.

Assay ID for HCMV is Pa03453400_s1, the gene symbol is UL132 and the catalogue number is 4331182. Assay ID for EBV is Pa03453399_s1, the gene symbol is IR1 and the catalogue number is $43 \overline{3} 1182$.

The sequences of HCMV and EBV used are as follows:

The assay is designed to a sequence that does not exhibit typical exon-intron-exon gene structure such as fusion transcript or artificial prokaryotic or mitochondrial sequences. As the assay procured from Applied Biosystem / Life technologies was inventoried, the individual HCMV and EBV primer and probe sequences are not provided or disclosed by the manufacturer.

\section{F. PCR procedure}

The PCR procedure was carried out in laboratory for molecular biology in Rajarajeswari Dental College and Hospital, Bangalore. Analysis of HCMV and EBV in the gingival crevicular fluid samples was done using quantitative real time polymerase chain reaction.

StepOne ${ }^{\mathrm{TM}}$ (48-well) Real-time PCR Systems by Life Technologies $^{\mathrm{TM}}$ and reagents from Applied Biosystems ${ }^{\mathrm{TM}}$ were used in this study. Custom TaqMan pathogen identification assay for HCMV and EBV was used in this study. TaqMan Polymerase Reaction was performed with a final volume of $20 \mu \mathrm{l}$ Polymerase Chain Reaction mixture containing (Table 1) 10 $\mu$ l TaqMan universal PCR mastermix (Applied biosystems), $1 \mu$ l custom TaqMan assay containing probes and primers for specific virus (Human Cytomegalovirus and Epstein-Barr virus), $3 \mu 1$ of extracted DNA sample and $6 \mu 1$ RNAse free water to make up to $20 \mu 1$. 
Each virus was identified in separate reaction for each sample.

TABLE 1: CONTENTS OF THE POLYMERASE CHAIN REACTION MIXTURE

\begin{tabular}{|c|c|}
\hline Contents of PCR mixture & Volume in $\boldsymbol{\mu l}$ \\
\hline TaqMan universal PCR mastermix & 10 \\
\hline $\begin{array}{c}\text { Custom TaqMan assay containing } \\
\text { probes and primers specific virus }\end{array}$ & 1 \\
\hline Extracted DNA sample & 3 \\
\hline RNAse free water & 6 \\
\hline Final volume of reaction mixture & $\mathbf{2 0}$ \\
\hline
\end{tabular}

The condition for Real Time Polymerase Chain Reaction was as follows. Pre-heating at $50^{\circ} \mathrm{C}$ for 2 minutes and at $95^{\circ} \mathrm{C}$ for 10 minutes, followed by 40 cycles of shuttle heating at $95^{\circ} \mathrm{C}$ for 15 seconds and at $60^{\circ} \mathrm{C}$ for 1 minute. $16 \mathrm{~s}$ RNA was used as the endogenous control (TaqMan predeveloped assay reagents Applied Biosystems - India). The comparative threshold cycle or $\mathrm{Ct}$ method was used to assess the amplified transcripts.

\section{STATISTICAL ANALYSIS}

The following methods of statistical analysis have been used in this study. Data was entered in Microsoft excel and analysed using SPSS (Statistical Package for Social Science, Ver.10.0.5) package.

The results were averaged (mean + standard deviation) for continuous data and number and percentage for dichotomous data are presented in Table and Figure. Normality of data was tested using Shapiro-Wilk test.

Proportions were compared using Chi-square $(\chi 2)$ test of significance. Proportion of cases belonging to specific group of parameter or having a particular problem was expressed in absolute number and percentage. The student ' $\mathrm{t}$ ' test was used to determine whether there was a statistical difference between groups in the parameters measured if the data is normal. One way analyses of variance were used to test the difference between groups. If $\mathrm{F}$ value is significant there is a significant, difference between group means. To find out which of the two groups means is significantly difference post hoc test of Tukey test is used. In case of F value is not significant it indicates that there is no significant difference between the groups and stops the analysis at this stage and does not used Tukey test.

The Kruskal-Wallis $\mathrm{H}$ test was used to determine if there are statistically significant differences between two or more groups of an independent variable on a continuous or ordinal dependent variable. Mann-Whitney $U$ test is used to compare differences between two independent groups when the dependent variable is either ordinal or continuous, but not normally distributed.

\section{RESULTS}

\section{A. Figures and Tables}

The present randomized controlled study was undertaken to quantitatively analyse the levels of HCMV and EBV in GCF samples obtained from chronic generalized periodontitis patients who were treated with scaling and root planing and diode laser. We also assessed the effect of diode laser on the prevelance of HCMV and EBV counts in GCF of chronic generalized periodontitis patients using quantitative polymerase chain reaction. The study population consisted of 30 subjects with 15 in each group.

Mean age of group 1 and group 2 was $43.93 \pm 5.65$ and $43.60 \pm 5.48$ respectively as shown in Table 2, 3 and Fig 1.

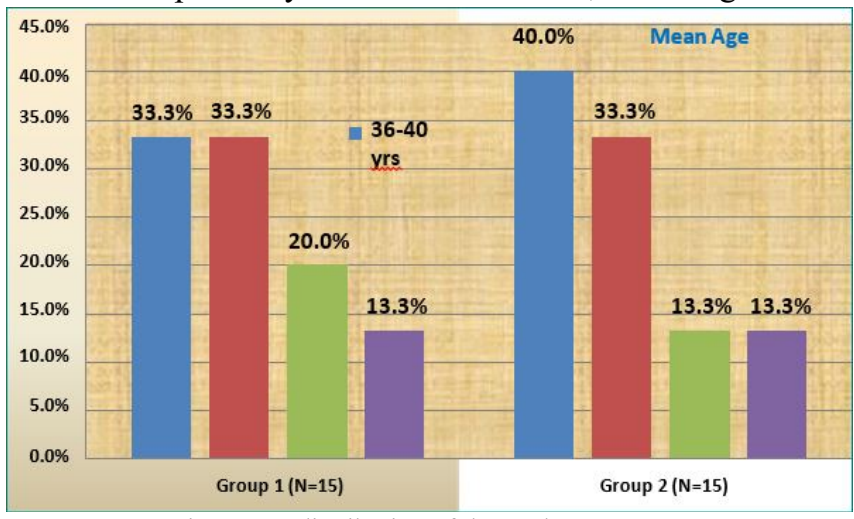

Fig 1: Age distribution of the study groups

\begin{tabular}{|l|c|l|l|l|l|l|l|l|}
\multicolumn{10}{|c|}{ TABLE 2: AGE DISTRIBUTION OF PATIENTS } \\
\hline Group & N & $\begin{array}{l}\text { Mean } \\
\text { age }\end{array}$ & SD & Median & Min. & Max. & $\begin{array}{l}\text { 't' } \\
\text { value }\end{array}$ & $\begin{array}{l}\text { 'p' } \\
\text { value }\end{array}$ \\
\hline $\begin{array}{l}\text { Group } \\
1\end{array}$ & 15 & 43.9 & 5.650 & 43.0 & 36 & 54 & & \\
\hline $\begin{array}{l}\text { Group } \\
2\end{array}$ & 15 & 43.6 & 5.475 & 44.0 & 36 & 54 & 0.027 & 0.871 \\
\hline
\end{tabular}

TABLE 3: DISTRIBUTION OF PATIENTS AMONG TWO GROUPS

\begin{tabular}{|c|c|c|c|c|c|c|c|c|}
\hline $\begin{array}{c}\text { Grou } \\
\mathrm{p}\end{array}$ & $\mathrm{N}$ & $\begin{array}{l}\text { Mea } \\
\mathrm{n} \text { age }\end{array}$ & SD & $\begin{array}{c}\text { Media } \\
n\end{array}$ & Min & Max & $\begin{array}{c}\text { ' } \mathrm{t} \text { ' } \\
\text { value }\end{array}$ & $\begin{array}{c}\text { tABL } \\
\text { E }\end{array}$ \\
\hline $\begin{array}{c}\text { Grou } \\
\text { p } 1\end{array}$ & $\begin{array}{l}1 \\
5\end{array}$ & 43.9 & $\begin{array}{c}5.65 \\
0\end{array}$ & 43.0 & 36 & 54 & \multirow{2}{*}{$\begin{array}{c}0.02 \\
7\end{array}$} & \multirow{2}{*}{0.871} \\
\hline Grou & 1 & 43.6 & $\begin{array}{c}5.47 \\
5\end{array}$ & 44.0 & 36 & 54 & & \\
\hline
\end{tabular}

In both the groups, maximum subjects were belonging to 31- 60 years. Gender was almost equally distributed in subjects in both groups (Table 4, Fig 2). Gender distribution of the subjects in the two different groups is shown in table 4 and figure 3 . Among 15 subjects in group 1, 8 males $(53.3 \%)$ and 7 females $(46.7 \%)$ were included in the study, and in group 2, it was 7 males $(46.7 \%)$ and 8 females $(53.3 \%)$.

TABLE 4: DISTRIBUTION OF PATIENTS AMONG TWO GROUPS BY GENDER

\begin{tabular}{|c|c|c|c|c|c|}
\hline & \multicolumn{2}{|c|}{ Gender } & & \multirow[b]{2}{*}{$\begin{array}{c}\chi^{2} \\
\text { value }\end{array}$} & \multirow[b]{2}{*}{ 'p' value } \\
\hline & Male & Female & & & \\
\hline \multirow{2}{*}{ Group 1} & 8 & 7 & 15 & \multirow{6}{*}{0.133} & \multirow{6}{*}{0.715} \\
\hline & $53.3 \%$ & $46.7 \%$ & $100.0 \%$ & & \\
\hline \multirow{2}{*}{ Group 2} & 7 & 8 & 15 & & \\
\hline & $46.7 \%$ & $53.3 \%$ & $100.0 \%$ & & \\
\hline \multirow{2}{*}{ Total } & 15 & 15 & 30 & & \\
\hline & $50.0 \%$ & $50.0 \%$ & $100.0 \%$ & & \\
\hline
\end{tabular}

TABLE 5: COMPARISON OF GINGIVAL INDEX BETWEEN TWO GROUPS AT BASELINE TO 7TH AND 21ST DAY.

\begin{tabular}{|c|c|c|c|c|c|c|c|c|c|}
\hline & & $\mathrm{N}$ & $\begin{array}{c}\mathrm{Me} \\
\text { an }\end{array}$ & SD & $\begin{array}{c}\text { Medi } \\
\text { an }\end{array}$ & $\begin{array}{c}\mathrm{Mi} \\
\mathrm{n} .\end{array}$ & $\begin{array}{c}\mathrm{Mi} \\
\mathrm{n} .\end{array}$ & $\begin{array}{c}\text { Mann } \\
- \\
\text { Whitn } \\
\text { ey U }\end{array}$ & $\begin{array}{c}\text { 'p' } \\
\text { val } \\
\text { ue }\end{array}$ \\
\hline \multirow{3}{*}{$\begin{array}{c}\text { Baseli } \\
\text { ne }\end{array}$} & Gro & 1 & 2.4 & 0.1 & 2.30 & 2.2 & 2.6 & \multirow{3}{*}{$\begin{array}{c}101.0 \\
0\end{array}$} & \multirow{3}{*}{$\begin{array}{c}0.6 \\
10\end{array}$} \\
\hline & up 1 & 5 & 0 & 46 & & & & & \\
\hline & $\begin{array}{l}\text { Gro } \\
\text { up } 2\end{array}$ & $\begin{array}{l}1 \\
5\end{array}$ & $\begin{array}{c}2.4 \\
2\end{array}$ & $\begin{array}{l}0.1 \\
37\end{array}$ & 2.30 & 2.3 & 2.6 & & \\
\hline \multirow[t]{2}{*}{7 days } & Gro & 1 & 1.5 & 0.1 & 1.50 & 1.3 & 1.3 & \multirow{2}{*}{$\begin{array}{c}45.00 \\
0\end{array}$} & \multirow{2}{*}{$\begin{array}{c}0.0 \\
03\end{array}$} \\
\hline & up 1 & $\begin{array}{l}5 \\
1\end{array}$ & $\frac{1}{13}$ & $\begin{array}{c}36 \\
00\end{array}$ & 130 & 13 & 13 & & \\
\hline
\end{tabular}




\begin{tabular}{|c|c|c|c|c|c|c|c|c|c|}
\hline & up 2 & 5 & 7 & 98 & & & & & \\
\hline \multirow{2}{*}{$\begin{array}{c}21 \\
\text { days }\end{array}$} & Gro & 1 & 1.1 & 0.1 & 1.20 & 0.9 & 0.9 & & \\
& up 1 & 5 & 6 & 24 & & & & 94.00 & 0.4 \\
& Gro & 1 & 1.1 & 0.1 & 1.00 & 0.8 & 0.8 & 0 & 24 \\
& up 2 & 5 & 1 & 71 & & & & & \\
\hline
\end{tabular}

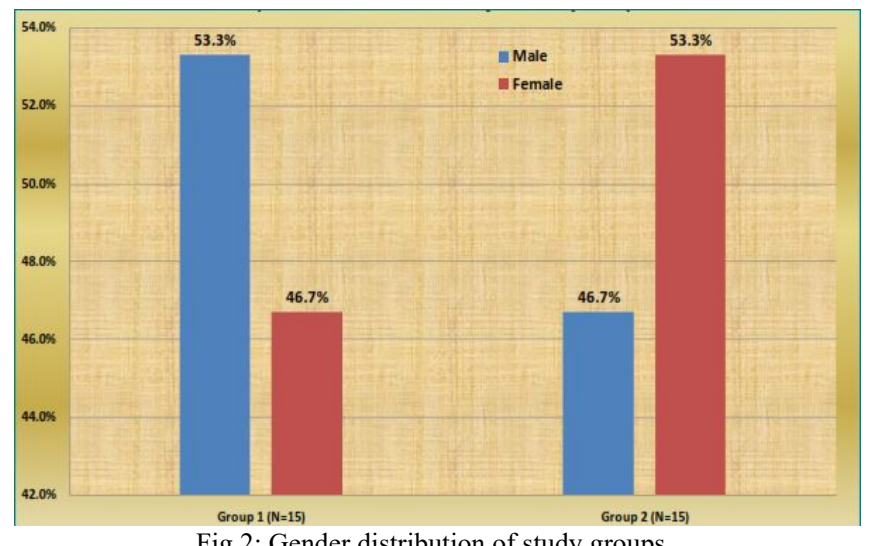

Fig 2: Gender distribution of study groups.

The difference in mean gingival index between group 1 and group 2 at various time intervals was statistically not significant (table 5, fig 3) whereas within each group the difference in mean gingival index was statistically significant at various time intervals. Pairwise comparison within group 1 and group 2 at various time intervals showed statistically significant difference (table 6, fig 4)

TABLE 6: COMPARISON GINGIVAL INDEX WITHIN EACH GROUP FROM BASELINE TO 7TH AND 21ST DAY.

\begin{tabular}{|c|c|c|c|c|c|c|c|c|c|}
\hline & & & $\begin{array}{l}\mathrm{Me} \\
\text { an }\end{array}$ & SD & $\begin{array}{l}\text { Medi } \\
\text { an }\end{array}$ & $\begin{array}{l}\mathrm{Mi} \\
\mathrm{n} .\end{array}$ & $\begin{array}{l}\text { Mi } \\
\text { n. }\end{array}$ & $\begin{array}{l}\text { Chisqu } \\
\text { re* }\end{array}$ & $\begin{array}{l}\text { 'p' } \\
\text { valu } \\
\text { e }\end{array}$ \\
\hline \multirow{3}{*}{$\begin{array}{l}\text { Gro } \\
\text { up } 1\end{array}$} & $\begin{array}{l}\text { Basel } \\
\text { ine }\end{array}$ & 5 & $\begin{array}{l}2.4 \\
0\end{array}$ & $\begin{array}{l}0.1 \\
46\end{array}$ & 2.30 & 2.2 & 2.6 & \multirow{3}{*}{$\begin{array}{l}332.46 \\
4\end{array}$} & \multirow{3}{*}{$\begin{array}{l}<0.0 \\
01\end{array}$} \\
\hline & $\begin{array}{r}7 \\
\text { days }\end{array}$ & 5 & $\begin{array}{l}1.5 \\
1\end{array}$ & $\begin{array}{l}0.1 \\
36\end{array}$ & 1.50 & 1.3 & 1.7 & & \\
\hline & $\begin{array}{c}21 \\
\text { days }\end{array}$ & 5 & $\begin{array}{l}1.1 \\
6\end{array}$ & $\begin{array}{l}0.1 \\
24\end{array}$ & 1.20 & 0.9 & 1.3 & & \\
\hline \multirow{3}{*}{$\begin{array}{l}\text { Gro } \\
\text { up } 2\end{array}$} & $\begin{array}{r}\mathrm{Ba} \\
\text { seline }\end{array}$ & 5 & $\begin{array}{l}2.4 \\
2\end{array}$ & $\begin{array}{l}0.1 \\
37\end{array}$ & 2.30 & 2.3 & 2.6 & \multirow{3}{*}{$\begin{array}{l}377.73 \\
4\end{array}$} & \multirow{3}{*}{$\begin{array}{l}\quad< \\
0.00 \\
1\end{array}$} \\
\hline & $\begin{array}{r}7 \\
\text { days }\end{array}$ & 5 & $\begin{array}{l}1.3 \\
7\end{array}$ & $\begin{array}{l}0.0 \\
98\end{array}$ & 1.30 & 1.3 & 1.5 & & \\
\hline & $\begin{array}{c}21 \\
\text { days }\end{array}$ & 5 & $\begin{array}{l}1.1 \\
1\end{array}$ & $\begin{array}{l}0.1 \\
71\end{array}$ & 1.00 & 0.8 & 1.3 & & \\
\hline
\end{tabular}

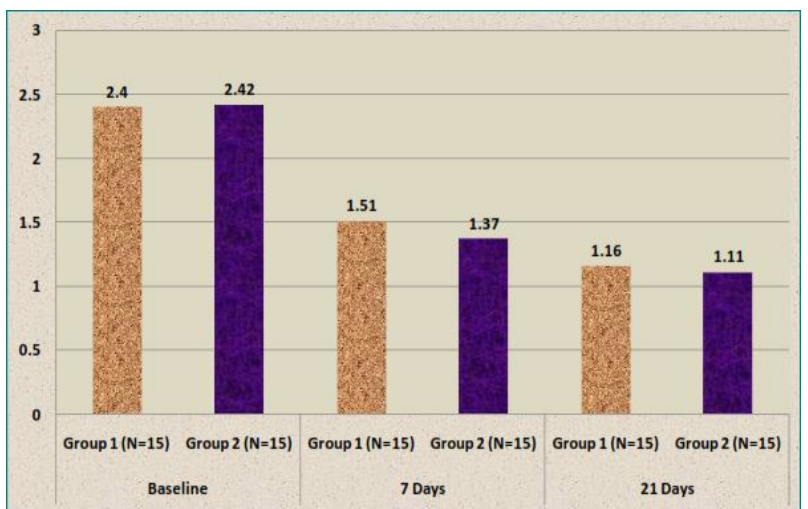

Fig 3: Comparision of Gingival Index between Study groups at baseline to 7 and 21 days

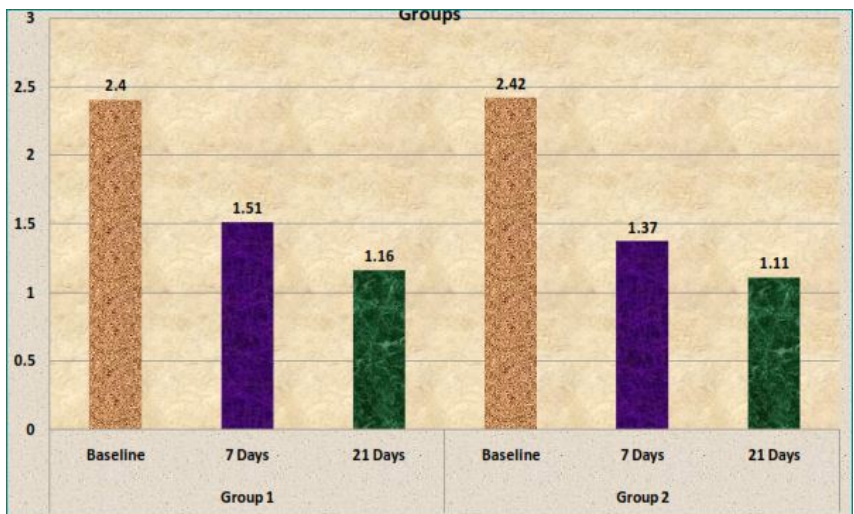

Fig 4: Comparision of Gingival Index between different visit by Study Groups

The difference in mean pocket depth between group 1 and group 2 at various time intervals was not statistically significant (table 7, fig 5). Within each group the difference in mean probing pocket depth at various time intervals was statistically significant. Pairwise comparison within group 1 and group 2 at various time intervals showed statistically significant difference (table 8 , fig 6)

TABLE 7-COMPARISON OF PROBING POCKET DEPTH BETWEEN TWO GROUPS FROM BASELINE TO 7TH AND 21ST DAY.

\begin{tabular}{|c|c|c|c|c|c|c|c|c|c|}
\hline Visit & $\begin{array}{c}\text { Gro } \\
\text { up }\end{array}$ & $\mathrm{N}$ & $\begin{array}{c}\text { Mea } \\
\mathrm{n}\end{array}$ & SD & $\begin{array}{c}\text { Medi } \\
\text { an }\end{array}$ & $\begin{array}{c}\mathrm{Mi} \\
\mathrm{n} .\end{array}$ & $\begin{array}{c}\mathrm{Mi} \\
\mathrm{n} .\end{array}$ & $\begin{array}{c}\mathrm{t} \text { ' } \\
\text { valu } \\
\mathrm{e}\end{array}$ & $\begin{array}{c}\text { 'p' } \\
\text { valu } \\
\mathrm{e}\end{array}$ \\
\hline \multirow[t]{2}{*}{$\begin{array}{c}\text { Baseli } \\
\text { ne }\end{array}$} & $\begin{array}{l}\text { Gro } \\
\text { up } 1\end{array}$ & 5 & 6.95 & $\begin{array}{c}0.35 \\
0\end{array}$ & 7.00 & 6.3 & 7.5 & \multirow{2}{*}{$\begin{array}{c}0.00 \\
3\end{array}$} & \multirow{2}{*}{$\begin{array}{c}0.95 \\
9\end{array}$} \\
\hline & $\begin{array}{l}\text { Gro } \\
\text { up } 2\end{array}$ & 5 & 6.95 & $\begin{array}{c}0.34 \\
6\end{array}$ & 6.90 & 6.3 & 7.5 & & \\
\hline \multirow[t]{2}{*}{7 days } & $\begin{array}{l}\text { Gro } \\
\text { up } 1\end{array}$ & 5 & 6.10 & $\begin{array}{c}0.29 \\
5\end{array}$ & 6.10 & 5.5 & 6.5 & \multirow{2}{*}{$\begin{array}{c}0.27 \\
7\end{array}$} & \multirow{2}{*}{$\begin{array}{c}0.60 \\
3\end{array}$} \\
\hline & $\begin{array}{l}\text { Gro } \\
\text { up } 2\end{array}$ & 5 & 6.15 & $\begin{array}{c}0.25 \\
9\end{array}$ & 6.10 & 5.5 & 6.5 & & \\
\hline \multirow[t]{2}{*}{$\begin{array}{c}21 \\
\text { days }\end{array}$} & $\begin{array}{l}\text { Gro } \\
\text { up } 1\end{array}$ & 5 & 5.68 & $\begin{array}{c}0.31 \\
2\end{array}$ & 5.60 & 5.2 & 6.3 & \multirow{2}{*}{$\begin{array}{c}2.40 \\
0\end{array}$} & \multirow{2}{*}{$\begin{array}{c}0.13 \\
3\end{array}$} \\
\hline & $\begin{array}{c}\text { Gro } \\
\text { up } 2\end{array}$ & 5 & 5.83 & $\begin{array}{c}0.22 \\
3\end{array}$ & 5.80 & 5.3 & 6.2 & & \\
\hline
\end{tabular}

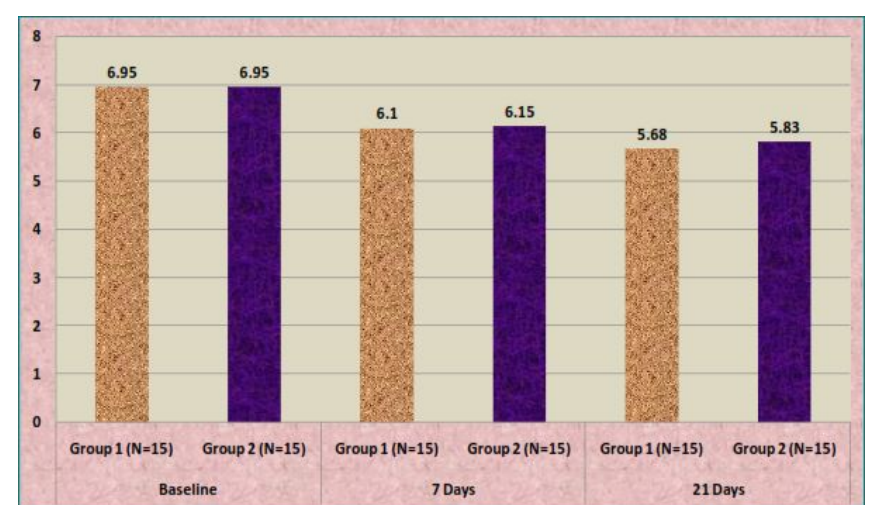

Fig 5: Comparision of Probing Pocket Depth between Study groups at baseline to 7 and 21 days

TABLE 8-COMPARISION OF PROBING POCKET DEPTH WITHIN EACH GROUP FROM BASELINE TO 7TH AND 21ST DAY.

\begin{tabular}{|c|c|c|c|c|c|c|c|c|c|}
\hline $\begin{array}{l}\text { Gro } \\
\text { up }\end{array}$ & $\begin{array}{l}\mathrm{Vi} \\
\text { sit }\end{array}$ & $\mathrm{N}$ & $\begin{array}{l}\mathrm{Me} \\
\text { an }\end{array}$ & SD & $\begin{array}{l}\text { Medi } \\
\text { an }\end{array}$ & $\begin{array}{l}\text { Mi } \\
\text { n. }\end{array}$ & $\begin{array}{l}\mathrm{Mi} \\
\mathrm{n} .\end{array}$ & $\begin{array}{l}\text { 'F' } \\
\text { valu } \\
\text { e }\end{array}$ & $\begin{array}{l}\text { 'p' } \\
\text { valu } \\
\text { e }\end{array}$ \\
\hline \multirow{3}{*}{$\begin{array}{l}\text { Gro } \\
\text { up } 1\end{array}$} & $\begin{array}{l}\text { Baseli } \\
\text { ne }\end{array}$ & 5 & $\begin{array}{l}6.9 \\
5\end{array}$ & $\begin{array}{l}0.3 \\
50\end{array}$ & 7.00 & 6.3 & 7.5 & \multirow{3}{*}{$\begin{array}{l}60.9 \\
71\end{array}$} & \multirow{3}{*}{$\begin{array}{l}<0.0 \\
01\end{array}$} \\
\hline & 7 days & 5 & $\begin{array}{l}6.1 \\
0\end{array}$ & $\begin{array}{l}0.2 \\
95\end{array}$ & 6.10 & 5.5 & 6.5 & & \\
\hline & $\begin{array}{l}21 \\
\text { days }\end{array}$ & 5 & $\begin{array}{l}5.6 \\
8\end{array}$ & $\begin{array}{l}0.3 \\
12\end{array}$ & 5.60 & 5.2 & 6.3 & & \\
\hline $\begin{array}{l}\text { Gro } \\
\text { up } 2\end{array}$ & $\begin{array}{l}\text { Baseli } \\
\text { ne }\end{array}$ & 5 & $\begin{array}{l}6.9 \\
5\end{array}$ & $\begin{array}{l}0.3 \\
46\end{array}$ & 6.90 & 6.3 & 7.5 & $\begin{array}{l}63.3 \\
81\end{array}$ & $\begin{array}{l}<0.0 \\
01\end{array}$ \\
\hline
\end{tabular}




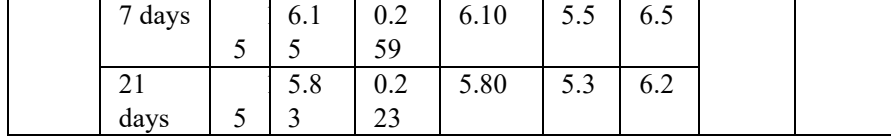

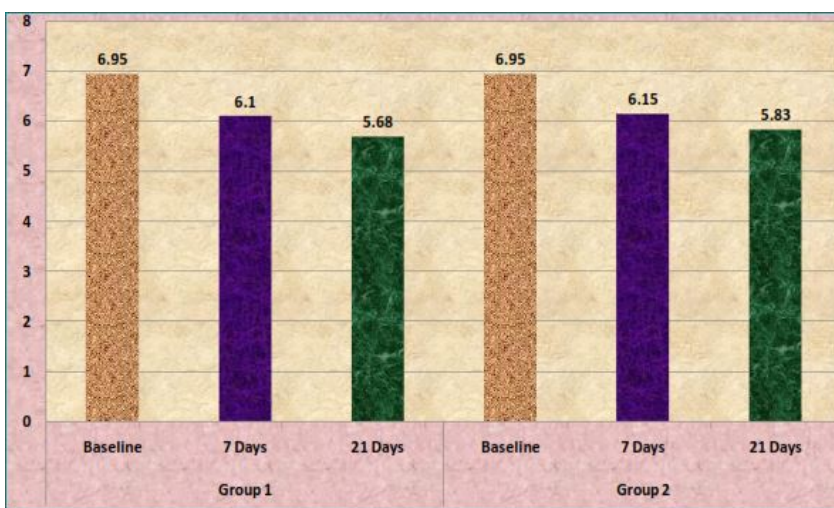

Fig 6: Comparision of Probing Pocket Depth between different visit by Study Groups

The difference in the mean clinical attachment loss in between group 1 and group 2 was statistically not significant. It is found that in group 1 the mean CAL at various time intervals was not statistically significant (table 9, fig 7). Intra group analysis of group 2 showed that the difference in mean CAL at various time intervals was statistically significant. Pairwise analysis in group 2 showed between baseline and 21st day was statistically significant, whereas group 1 at various time intervals was not significant (table 10, fig 8).

TABLE 9-COMPARISON OF CLINICAL ATTACHMENT LEVEL BETWEEN TWO GROUPS FROM BASELINE TO $7^{\mathrm{TH}}$ AND $21^{\mathrm{ST}}$ DAY.

\begin{tabular}{|c|c|c|c|c|c|c|c|c|c|}
\hline Visit & $\begin{array}{l}\text { Gro } \\
\text { up }\end{array}$ & $\mathrm{N}$ & $\begin{array}{l}\text { Mea } \\
\mathrm{n}\end{array}$ & SD & $\begin{array}{l}\text { Medi } \\
\text { an }\end{array}$ & $\begin{array}{l}\text { Mi } \\
\text { n. }\end{array}$ & $\begin{array}{l}\text { Mi } \\
\text { n. }\end{array}$ & $\begin{array}{l}\text { 't' } \\
\text { valu } \\
\mathrm{e}\end{array}$ & $\begin{array}{l}\text { 'p' } \\
\text { valu } \\
\text { e }\end{array}$ \\
\hline \multirow[t]{2}{*}{$\begin{array}{l}\text { Baseli } \\
\text { ne }\end{array}$} & $\begin{array}{l}\text { Gro } \\
\text { up } 1\end{array}$ & 5 & 7.07 & $\begin{array}{l}0.40 \\
3\end{array}$ & 7.20 & 6.3 & 7.5 & \multirow{2}{*}{$\begin{array}{l}1.00 \\
5\end{array}$} & \multirow{2}{*}{$\begin{array}{l}0.32 \\
5\end{array}$} \\
\hline & $\begin{array}{l}\text { Gro } \\
\text { up } 2\end{array}$ & 5 & 7.20 & $\begin{array}{l}0.32 \\
1\end{array}$ & 7.30 & 6.6 & 7.6 & & \\
\hline \multirow[t]{2}{*}{7 days } & $\begin{array}{l}\text { Gro } \\
\text { up } 1\end{array}$ & 5 & 6.80 & $\begin{array}{l}0.43 \\
4\end{array}$ & 7.00 & 6.0 & 7.3 & \multirow{2}{*}{$\begin{array}{l}0.39 \\
5\end{array}$} & \multirow{2}{*}{$\begin{array}{l}0.53 \\
5\end{array}$} \\
\hline & $\begin{array}{l}\text { Gro } \\
\text { up } 2\end{array}$ & 5 & 6.89 & $\begin{array}{l}0.37 \\
7 \\
\end{array}$ & $\begin{array}{l}7.00 \\
\end{array}$ & 6.3 & 7.3 & & \\
\hline \multirow[t]{2}{*}{$\begin{array}{l}21 \\
\text { days }\end{array}$} & $\begin{array}{l}\text { Gro } \\
\text { up 1 }\end{array}$ & 5 & 6.67 & $\begin{array}{l}0.39 \\
8\end{array}$ & 7.00 & 6.0 & 7.0 & \multirow{2}{*}{$\begin{array}{l}0.81 \\
0\end{array}$} & \multirow{2}{*}{$\begin{array}{l}0.37 \\
6\end{array}$} \\
\hline & $\begin{array}{l}\text { Gro } \\
\text { up } 2\end{array}$ & 5 & 6.55 & $\begin{array}{l}0.28 \\
3\end{array}$ & 6.50 & 6.0 & 7.0 & & \\
\hline
\end{tabular}

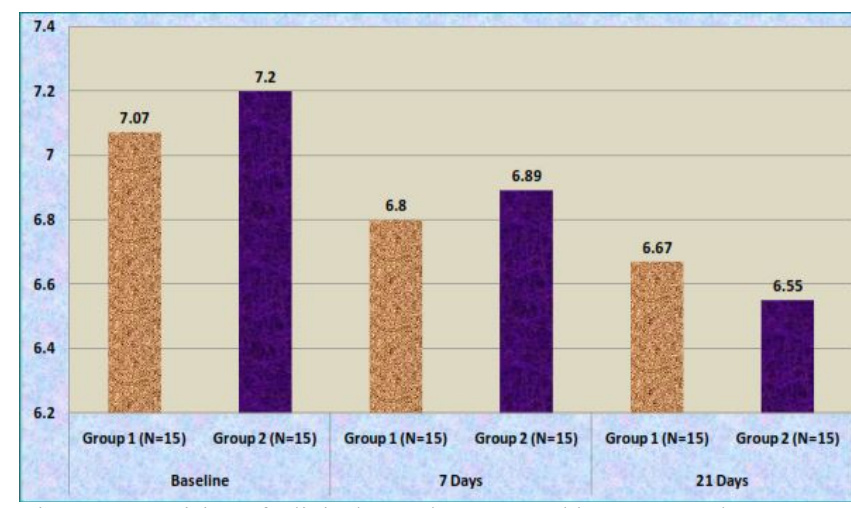

Fig 7: Comparision of Clinical Attachment Level between Study groups at baseline to 7 and 21 days

TABLE 10-COMPARISON OF CLINICAL ATTACHMENT LEVEL WITHIN EACH GROUP FROM BASELINE TO $7^{\mathrm{TH}}$ AND $21^{\mathrm{ST}}$ DAY.

\begin{tabular}{|l|l|l|l|l|l|l|l|l|l|}
\hline $\begin{array}{l}\text { Gro } \\
\text { up }\end{array}$ & Visit & N & $\begin{array}{l}\text { Me } \\
\text { an }\end{array}$ & SD & $\begin{array}{l}\text { Medi } \\
\text { an }\end{array}$ & $\begin{array}{l}\text { Mi } \\
\text { n. }\end{array}$ & $\begin{array}{l}\text { Mi } \\
\text { n. }\end{array}$ & $\begin{array}{l}\text { 'F' } \\
\text { valu } \\
\text { e }\end{array}$ & $\begin{array}{l}\text { 'p' } \\
\text { valu } \\
\text { e }\end{array}$ \\
\hline
\end{tabular}

\begin{tabular}{|c|c|c|c|c|c|c|c|c|c|}
\hline \multirow{3}{*}{$\begin{array}{l}\text { Gro } \\
\text { up } 1\end{array}$} & $\begin{array}{l}\text { Baseli } \\
\text { ne }\end{array}$ & 5 & $\begin{array}{l}7.0 \\
7\end{array}$ & $\begin{array}{l}0.4 \\
03\end{array}$ & 7.20 & 6.3 & 7.5 & \multirow{3}{*}{$\begin{array}{l}3.66 \\
7\end{array}$} & \multirow{3}{*}{$\begin{array}{l}0.03 \\
4\end{array}$} \\
\hline & 7 days & 5 & $\begin{array}{l}6.8 \\
0\end{array}$ & $\begin{array}{l}0.4 \\
34\end{array}$ & 7.00 & 6.0 & 7.3 & & \\
\hline & $\begin{array}{l}21 \\
\text { days }\end{array}$ & 5 & $\begin{array}{l}6.6 \\
7\end{array}$ & $\begin{array}{l}0.3 \\
98\end{array}$ & 7.00 & 6.0 & 7.0 & & \\
\hline \multirow{3}{*}{$\begin{array}{l}\text { Gro } \\
\text { up } 2\end{array}$} & $\begin{array}{l}\text { Baseli } \\
\text { ne }\end{array}$ & 5 & $\begin{array}{l}7.2 \\
0 \\
\end{array}$ & $\begin{array}{l}0.3 \\
21 \\
\end{array}$ & 7.30 & 6.6 & 7.6 & \multirow{3}{*}{$\begin{array}{l}14.4 \\
99\end{array}$} & \multirow{3}{*}{$\begin{array}{l}<0.0 \\
01\end{array}$} \\
\hline & 7 days & 5 & $\begin{array}{l}6.8 \\
9\end{array}$ & $\begin{array}{l}0.3 \\
77\end{array}$ & 7.00 & 6.3 & 7.3 & & \\
\hline & $\begin{array}{r}21 \\
\text { days }\end{array}$ & 5 & $\begin{array}{l}6.5 \\
5\end{array}$ & $\begin{array}{l}0.2 \\
83\end{array}$ & 6.50 & 6.0 & 7.0 & & \\
\hline
\end{tabular}

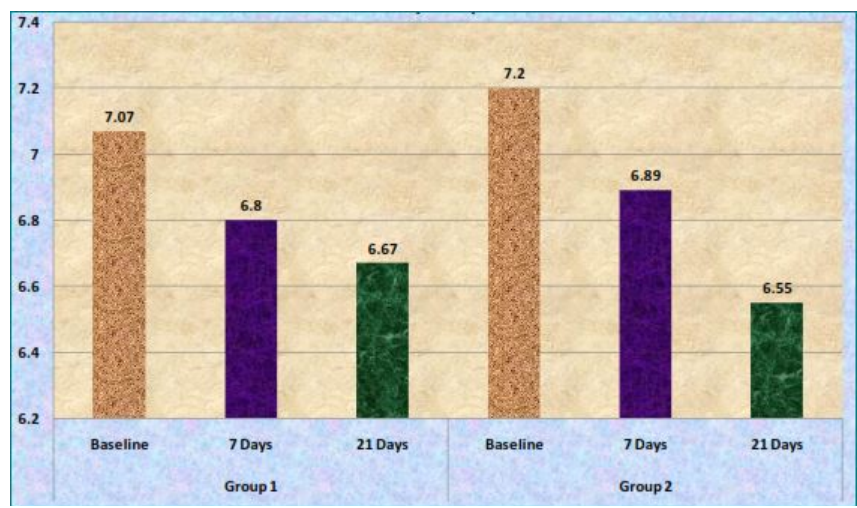

Fig 8: Comparision of Clincial Attachment level between different visit by Study Groups

The difference in the mean RQ of EBV value in group 1 and group 2 at various time intervals was not statistically significant (table 11, fig 9). Within group 1 the mean RQ value of EBV at baseline, 7 and 21 days were 28.53, 19.52 and 0.19 respectively. The difference in mean RQ values in the above said intervals was statistically significant $(\mathrm{p}<0.001)$. Within group 2 the mean RQ value of EBV at baseline, 7th and 21st days were 21.88, 3.36 and 0.05 respectively. The difference in mean RQ values in the above said intervals was statistically significant $(p<0.001)$ (table 12, fig 10).

TABLE 11 - COMPARISON OF RELATIVE QUANTIFICATION OF EBV SCORES BY MANN- WHITNEY U TEST BETWEEN TWO GROUPS FROM BASELINE TO $7^{\mathrm{TH}}$ AND $21^{\mathrm{ST}}$ DAY.

\begin{tabular}{|c|c|c|c|c|c|c|c|c|c|}
\hline Visit & $\begin{array}{l}\text { Gro } \\
\text { up }\end{array}$ & $\mathrm{N}$ & $\begin{array}{l}\text { Mea } \\
\mathrm{n}\end{array}$ & SD & $\begin{array}{l}\text { Medi } \\
\text { an }\end{array}$ & $\begin{array}{l}\mathrm{Mi} \\
\mathrm{n} .\end{array}$ & $\begin{array}{l}\text { Mi } \\
\text { n. }\end{array}$ & $\begin{array}{l}\text { Mann } \\
- \\
\text { Whit } \\
\text { ney U }\end{array}$ & $\begin{array}{l}\text { 'p' } \\
\text { val } \\
\text { ue }\end{array}$ \\
\hline \multirow[t]{2}{*}{$\begin{array}{l}\text { Basel } \\
\text { ine }\end{array}$} & $\begin{array}{l}\text { Gro } \\
\text { up } 1\end{array}$ & 5 & $\begin{array}{l}28.5 \\
31\end{array}$ & $\begin{array}{l}25.5 \\
21\end{array}$ & $\begin{array}{l}26.1 \\
82\end{array}$ & $\begin{array}{l}3.9 \\
7\end{array}$ & $\begin{array}{l}79 . \\
84\end{array}$ & \multirow{2}{*}{$\begin{array}{l}32.00 \\
0\end{array}$} & \multirow{2}{*}{$\begin{array}{l}0.4 \\
70\end{array}$} \\
\hline & $\begin{array}{l}\text { Gro } \\
\text { up } 2\end{array}$ & 5 & $\begin{array}{l}21.8 \\
86\end{array}$ & $\begin{array}{l}24.0 \\
98\end{array}$ & $\begin{array}{l}13.4 \\
32\end{array}$ & $\begin{array}{l}1.0 \\
0\end{array}$ & $\begin{array}{l}79 . \\
84\end{array}$ & & \\
\hline \multirow[t]{2}{*}{$\begin{array}{l}7 \\
\text { days }\end{array}$} & $\begin{array}{l}\text { Gro } \\
\text { up 1 }\end{array}$ & 5 & $\begin{array}{l}19.5 \\
26 \\
\end{array}$ & $\begin{array}{l}28.5 \\
26 \\
\end{array}$ & $\begin{array}{l}7.68 \\
8 \\
\end{array}$ & $\begin{array}{l}1.0 \\
6 \\
\end{array}$ & $\begin{array}{l}61 . \\
67 \\
\end{array}$ & \multirow{2}{*}{4.500} & \multirow{2}{*}{$\begin{array}{l}0.1 \\
76\end{array}$} \\
\hline & $\begin{array}{l}\text { Gro } \\
\text { up } 2\end{array}$ & 5 & $\begin{array}{l}3.36 \\
7\end{array}$ & $\begin{array}{l}5.10 \\
8\end{array}$ & $\begin{array}{l}1.84 \\
3\end{array}$ & $\begin{array}{l}0.0 \\
3\end{array}$ & $\begin{array}{l}12 . \\
37\end{array}$ & & \\
\hline \multirow[t]{2}{*}{$\begin{array}{l}21 \\
\text { days }\end{array}$} & $\begin{array}{l}\text { Gro } \\
\text { up } 1\end{array}$ & 5 & $\begin{array}{l}0.19 \\
9\end{array}$ & $\begin{array}{l}0.33 \\
5\end{array}$ & $\begin{array}{l}0.07 \\
3\end{array}$ & $\begin{array}{l}0.0 \\
0\end{array}$ & $\begin{array}{l}1.0 \\
6\end{array}$ & \multirow{2}{*}{$\begin{array}{l}21.00 \\
0\end{array}$} & \multirow{2}{*}{$\begin{array}{l}0.2 \\
66\end{array}$} \\
\hline & $\begin{array}{l}\text { Gro } \\
\text { up } 2\end{array}$ & 5 & $\begin{array}{l}0.05 \\
0\end{array}$ & $\begin{array}{l}0.05 \\
4\end{array}$ & $\begin{array}{l}0.01 \\
8\end{array}$ & $\begin{array}{l}0.0 \\
0\end{array}$ & $\begin{array}{l}0.1 \\
4\end{array}$ & & \\
\hline
\end{tabular}




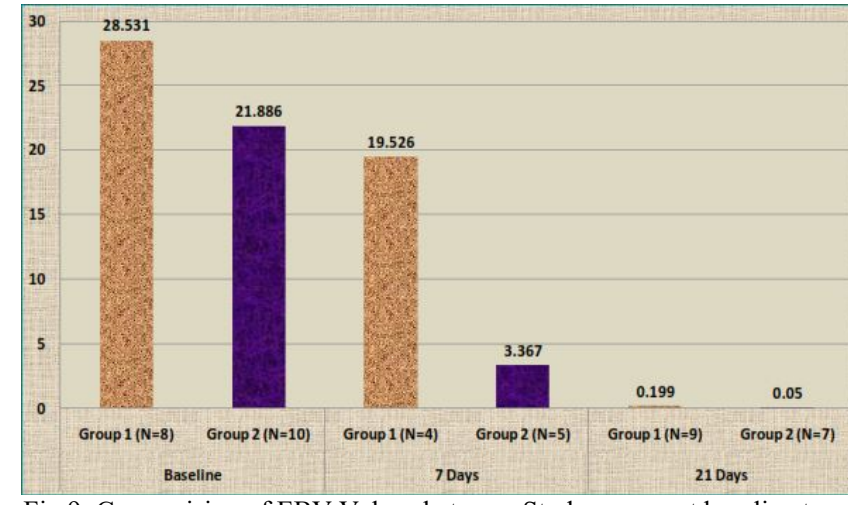

Fig 9: Comparision of EBV Values between Study groups at baseline to 7 and 21 days

TABLE 12 - COMPARISON OF RELATIVE QUANTIFICATION OF EBV SCORES BY CHISQUARE TEST IN EACH GROUP FROM BASELINE TO $7^{\mathrm{TH}}$ AND $21^{\mathrm{ST}}$ DAY.

\begin{tabular}{|c|c|c|c|c|c|c|c|c|c|}
\hline $\begin{array}{l}\text { Gro } \\
\text { up }\end{array}$ & Visit & $\mathrm{N}$ & $\begin{array}{l}\text { Mea } \\
\mathrm{n}\end{array}$ & SD & $\begin{array}{l}\text { Med } \\
\text { ian }\end{array}$ & $\begin{array}{l}\mathrm{Mi} \\
\mathrm{n} .\end{array}$ & $\begin{array}{l}\mathrm{Mi} \\
\mathrm{n} .\end{array}$ & $\begin{array}{l}\text { Chisq } \\
\text { ure* }\end{array}$ & $\begin{array}{l}\text { 'p' } \\
\text { valu } \\
\text { e }\end{array}$ \\
\hline \multirow{3}{*}{$\begin{array}{l}\text { Gro } \\
\text { up } 1\end{array}$} & $\begin{array}{l}\text { Basel } \\
\text { ine }\end{array}$ & 5 & $\begin{array}{l}28.5 \\
31\end{array}$ & $\begin{array}{l}25.5 \\
21\end{array}$ & $\begin{array}{l}26.1 \\
82\end{array}$ & $\begin{array}{l}3.9 \\
7\end{array}$ & $\begin{array}{l}79 . \\
84\end{array}$ & \multirow{3}{*}{14.797} & \multirow{3}{*}{$\begin{array}{l}<0.0 \\
01\end{array}$} \\
\hline & $\begin{array}{l}7 \\
\text { days }\end{array}$ & 5 & $\begin{array}{l}19.5 \\
26\end{array}$ & $\begin{array}{l}28.5 \\
26\end{array}$ & $\begin{array}{l}7.68 \\
8\end{array}$ & $\begin{array}{l}1.0 \\
6\end{array}$ & $\begin{array}{l}61 . \\
67\end{array}$ & & \\
\hline & $\begin{array}{l}21 \\
\text { days }\end{array}$ & 5 & $\begin{array}{l}0.19 \\
9\end{array}$ & $\begin{array}{l}0.33 \\
5\end{array}$ & $\begin{array}{l}0.07 \\
3\end{array}$ & $\begin{array}{l}0.0 \\
0\end{array}$ & $\begin{array}{l}1.0 \\
6\end{array}$ & & \\
\hline \multirow{3}{*}{$\begin{array}{l}\text { Gro } \\
\text { up } 2\end{array}$} & $\begin{array}{l}\text { Basel } \\
\text { ine }\end{array}$ & 5 & $\begin{array}{l}21.8 \\
86\end{array}$ & $\begin{array}{l}24.0 \\
98\end{array}$ & $\begin{array}{l}13.4 \\
32\end{array}$ & $\begin{array}{l}1.0 \\
0\end{array}$ & $\begin{array}{l}79 . \\
84\end{array}$ & \multirow{3}{*}{14.652} & \multirow{3}{*}{$\begin{array}{l}<0.0 \\
01\end{array}$} \\
\hline & $\begin{array}{l}7 \\
\text { days }\end{array}$ & 5 & $\begin{array}{l}3.36 \\
7\end{array}$ & $\begin{array}{l}5.10 \\
8\end{array}$ & $\begin{array}{l}1.84 \\
3\end{array}$ & $\begin{array}{l}0.0 \\
3\end{array}$ & $\begin{array}{l}12 . \\
37\end{array}$ & & \\
\hline & $\begin{array}{l}21 \\
\text { days }\end{array}$ & 5 & $\begin{array}{l}0.05 \\
0\end{array}$ & $\begin{array}{l}0.05 \\
4\end{array}$ & $\begin{array}{l}0.01 \\
8\end{array}$ & $\begin{array}{l}0.0 \\
0\end{array}$ & $\begin{array}{l}0.1 \\
4\end{array}$ & & \\
\hline
\end{tabular}

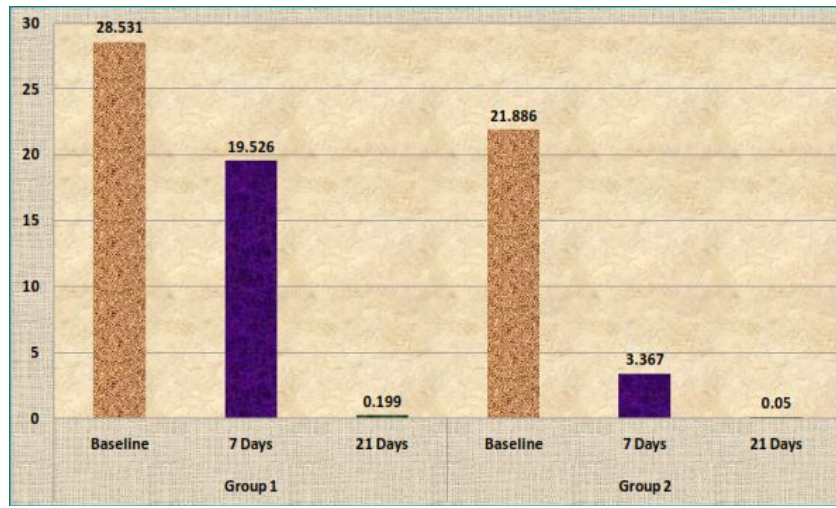

Fig 10: Comparision of EBV Values between different visit by Study Groups.

It was found that the effect of diode laser as an adjunct to SRP showed greater reduction of EBV levels in concentration in chronic generalized periodontitis patients compared to SRP.

Out of 90 samples of GCF taken from both the groups, EBV was present in most of the samples, whereas HCMV was not detected in any of the samples across the group. The prevalence of EBV was found higher in both the groups and also the quantity increased in line with higher clinical parameters.

\section{DISCUSSION}

The present randomized controlled trial was undertaken to determine the prevalence of human cytomegalovirus (HCMV) and Epstein-Barr virus (EBV) in gingival crevicular fluid (GCF) of chronic generalized periodontitis patients. We also evaluated the effect of scaling and root planing (SRP) and diode laser on the quantity of HCMV and
EBV in chronic generalized periodontitis patients using quantitative real time polymerase chain reaction. According to our knowledge this is the first study conducted in this regard.

Our results showed a high prevalence of EBV in GCF samples (46\% in group 1 and $60 \%$ in group 2) from deep periodontal pockets similar to studies conducted by Watanabe SA et al. 65 where they found a significantly higher occurrence of EBV in periodontal sites than in gingivitis sites. Watanabe et al [17] discussed that higher occurrence of EBV in deep periodontal sites is consistent with the herpes viruses playing a role in the pathogenesis of periodontitis.

Contreras A et al [18] reported that EBV was the second most prevalent virus detected occurring in $50 \%$ of tissue biopsy specimens and in $45 \%$ of B-lymphocyte fractions from the adult periodontitis lesions. EBV is a potent polyclonal B-lymphocyte activator, capable of inducing proliferation and differentiation of immunoglobulin secreting cells.

EBV affects over $90 \%$ of humans and is usually transmitted by oral secretions or blood. The virus replicates in epithelial cells or B-cells of the oropharynx. Resting memory B cells are the main site of persistence of EBV in the body. The number of latently infected cells in a person remains stable for over years [19] Latent EBV infection can be reactivated, leading to viral shedding into oral mucosa [20].

Konstantinidis et al [6] showed EBV to be present in 11 out of 12 chronic periodontitis patients and only one in healthy controls. Similarly, in aggressive periodontitis patients, EBV was found to be significant (32\%) compared with healthy controls $(8 \%)$. However, no difference was found between chronic periodontitis and aggressive periodontitis patients in this study. This is contradictory to the study results obtained by Kubar et al [21] where EBV was seen to be present in $89 \%$ sites in aggressive periodontitis patients compared with $46 \%$ in chronic periodontitis patients, which was statistically significant.

Some investigators have suggested that once EBV is present (or active), its herpes virus mediated impairment of the host defense may give rise to subgingival growth of periodontal pathogens and subsequent periodontal attachment loss [17], [22]. Saygun et al [23] found EBV in $44.3 \%$ of sites from patients with chronic periodontitis and only $14.3 \%$ of the sites obtained from healthy controls.

The results of the present study revealed an association between the presence of EBV and chronic periodontitis lesions $(\mathrm{PD}=5 \mathrm{~mm})$. Our results correlated with that of previous studies that showed statistically significant levels of EBV in patients with chronic periodontitis. Slots et al. discovered more EBV in the gingival crevicular fluid and saliva of patients with periodontal diseases than in the saliva of an otherwise healthy control group [4], [24]. The same group demonstrated a correlation between EBV prevalence in periodontal patients and periodontal pocket depth [21], [25], [26]. Because EBV detection using nested PCR is a qualitative test. The results showed that real-time PCR data was consistent with nested PCR data. Real-time PCR did detect the presence of EBV in those sites in which nested PCR had detected the presence of the DNA. In addition, 
least one order or more of EBV was detected in deeper probing depth sites compared with shallow probing depth sites.

Contreras et al [9] have detected HCMV in monocytes / macrophages and T lymphocytes, EBV in B lymphocytes, and HSV in T lymphocytes and monocytes / macrophages. Infected immune cells may not mount a proper immune response against periodontopathogenic bacteria predisposing to microbial superinfection. Herpes virus induced defective polymorphonuclear neutrophils can increase the risk for destructive periodontal disease. The above said study found herpes viruses infecting various types of inflammatory cells in periodontitis lesions. It was not known whether the infected cells carry functional or latent herpes viruses. Active herpes virus infections would potentially be more detrimental to the periodontium than latent herpes virus infections.

Previous studies have shown the association of HCMV to periodontitis sites, [4], [18], [21], [27], [23] which are in contrast with our results as HCMV was not detected in chronic periodontitis patient. This discrepancy may also be due to sample size, selection of the subjects evaluated, or ethnic differences. The absence of HCMV could denote the stability of periodontitis sites in the sample, since a previous study observed a higher frequency of HCMV in progressing periodontitis sites compared to that of stable sites [28].

In a study conducted by Ting et al [29] it was hypothesized that active HCMV infection could be associated with the initiation and progression of localized juvenile periodontitis. In another study conducted by Contreras and Slots [30] results suggested that active HCMV replication could occur in periodontitis sites, but it remained unclear if HCMV reactivation was related to the initiation or the progression of destructive periodontal disease.

The present findings are consistent with the premise that high levels of EBV in GCF samples reflect increased likelihood of several subgingival and periodontal sites having high EBV burden. In contrast, the low prevalence of HCMV in GCF samples suggests that this virus is an infrequent participant of periodontal disease in immunocompetent individuals. Interestingly, we did not observe a relationship between the presence and amount of HCMV in chronic generalized periodontitis patients.

Haffajee AD et al. had done a study to examine the effect of SRP on clinical and microbiological parameters in 57 subjects with adult periodontitis. Subjects were monitored clinically and microbiologically prior to and 3,6 and 9 months after full-mouth SRP under local anaesthesia. They observed that mean prevalences and levels of $\mathrm{P}$. gingivalis, T. denticola and B. forsythus were significantly reduced after SRP, while A. viscosus showed a significant increase in mean levels. The mean decrease in prevalence of $P$. gingivalis was similar at all pocket depth categories, while B. forsythus decreased more at shallow and intermediate pockets and A. viscosus increased most at deep sites. P. gingivalis. B. forsythus and T. denticola were equally prevalent. Clinical improvement post-SRP was accompanied by a modest change in the subgingival microbiota, primarily a reduction in $\mathrm{P}$. gingivalis, $\mathrm{B}$. forsythus and $\mathrm{T}$. denticola, suggesting potential targets for therapy and indicating that radical alterations in the subgingival microbiota.

Grenier $\mathrm{G}$ et al [31] determined the prevalence of human cytomegalovirus (HCMV), Epstein-Barr virus (EBV) and herpes simplex virus (HSV) in gingival crevicular fluid (GCF) samples obtained from periodontally healthy, gingivitis and periodontitis patients. In addition, the effect of periodontal treatment (scaling and root planing) on the persistence of herpetic viruses was evaluated in a sub-group of patients suffering from chronic periodontitis. They observed that there was a higher prevalence of HCMV was associated with deep periodontal pockets in subjects suffering from periodontitis. This said study showed that the prevalence of HCMV and HSV viruses in GCF is higher in patients suffering from periodontitis compared to periodontally healthy subjects, and that the prevalence of HCMV is higher in deep periodontal pockets. It also brought evidences that periodontal therapy may be associated with virus elimination in diseased sites.

Laser therapy has been proposed as an alternative or adjunctive treatment to conventional periodontal therapy. A variety of lasers have been proposed, including the $\mathrm{CO}$; neodymium doped:yttrium, aluminum, and garnet (Nd:YAG); diode; and erbium-doped: YAG (Er:YAG) lasers.

The bactericidal and detoxifying effects of the diode laser during non-surgical periodontal treatment have been documented [32], [33]. For patients with periodontitis, the adjunctive use of a diode laser with scaling and root planing (SRP) has shown a superior effect over SRP or the laser alone for certain microbial and clinical parameters [34]

Diode lasers (810-980 $\mathrm{nm}$ range) emit laser light in the near infra-red spectrum of the electromagnetic radiation which are highly absorbed in haemoglobin and other pigments. One of the main benefits of using diode lasers is the ability to selectively and precisely interact with diseased tissues. Lasers also allow the clinician to reduce the amount of bacteria and other pathogens in the surgical field and in the case of soft-tissue procedures, achieve good haemostasis without sutures [35], [17].

The purported advantages of diode lasers versus conventional surgery include increased coagulation that yields a dry surgical field and better visualization; the ability to negotiate curvatures and folds within tissue contours; tissue surface sterilization and therefore, reduction in bacteraemia; decreased swelling, edema, and scarring; decreased pain; faster healing response; and increased patient acceptance [17].

When laser cutting is in progress, small blood and lymphatic vessels are sealed due to the generated heat, thereby reducing or eliminating bleeding and edema. Denatured proteins within tissue and plasma are the source of the layer termed "coagulum", which is formed because of laser action and serves to protect the wound from bacterial or frictional action. Also the diode laser did not produce any deleterious effect on the root surface. Therefore, diode laser surgery can be performed safely in close proximity to dental hard tissue. During SRP procedure, there was no bleeding and postoperatively no pain was experienced by the patient and no swelling or any other signs of infection were noticed, whereas conventional procedures require the administration of antibiotics and analgesics to minimize postoperative 
infection and pain [35].

In the present study a significant reduction of mean relative quantification (RQ) values of $E B V$ in relation to 16sRNA in GCF samples of chronic generalized periodontitis patients was observed. The mean RQ values of EBV at baseline (28.53) was reduced to 0.19 on 21 st day in group 1 and in group 2 it was reduced to 0.05 from 21.86

\section{CONCLUSION}

It was found that the effect of diode laser as an adjunct to Scaling and root planing (SRP) showed greater reduction of EBV levels concentration in chronic generalized periodontitis patients compared to SRP and we also observed marked improvement of clinical parameters (GI, PPD and CAL) from baseline to 7 th and 21st day.

The higher prevalence of EBV in the GCF of chronic generalised periodontitis patients suggest that EBV may play an important role in the pathogenesis of chronic periodontitis.

Within the limitations, we suggest that diode laser provides improvement in clinical and biochemical benefits over conventional mechanical treatment during medium term of observation.

\section{ACKNOWLEDGMENT}

No commercial relationship or conflict of interest with any of the products used in this investigation, and the study is designed by our own initiative. Our study was self-funded by the authors and the institution.

\section{REFERENCES}

[1] Ezzo PJ, Cutler CW. Microorganisms as risk indicators for periodontal disease. Periodontol 2000; 2003; 32: 24.

[2] Slots J, Chen C. The oral microflora and human periodontal disease. In: Tannock GW, editor. Medical Importance of the Normal Microflora. London: Kluwer Academic Publishers 1999: 101-127.

[3] Wu YM, Yan J, Ojcius DM, Chen LL, Gu ZY, Pan JP. Correlation between Infections with Different Genotypes of Human Cytomegalovirus and Epstein - Barr virus in Subgingival Samples and Periodontal Status of Patients, J Clin Microbiol 2007; 45: 3665-3670.

[4] Contreras A, Slots J. Herpesviruses in human periodontal disease. J. Periodontal Res 2000. 35:3-16.

[5] Idesawa M, Sugano N, Ikeda K, Oshikawa M, Takane M, Seki K et al. Detection of Epstein-Barr virus in saliva by real-time PCR. Oral Microbiol Immunol 2004; 19:230-232.

[6] Konstantinidis A, Sakellari D, Papa A, Antoniadis A. Real-time polymerase chain reaction quantification of Epstein-Barr virus in chronic periodontitis patients. J.Periodontal Res 2005 40:294-298.

[7] Saygun I, Yapar M, Ozdemir A, Kubar A, Slots S. Human cytomegalovirus and Epstein-Barr virus type 1 in periodontal abscesses. Oral Microbiol Immunol 2004;19: 83-87.

[8] Slots J, Contreras A. Herpesviruses: a unifying causative factor in periodontitis? Oral Microbiol Immunol 2000; 15: 276-279

[9] Contreras A, Zadeh HH, Nowzari H, Slots J. Herpesvirus infection of inflammatory cells in human periodontitis. Oral Microbiol Immunol 1999; 14(4):206-12.

[10] Slots J. Herpesviral-bacterial synergy in the pathogenesis of human periodontitis. Curr Opin Infect Dis 2007; 20:278-283.

[11] Kamma J J, Slots J. Herpesviral-bacterial interactions in aggressive periodontitis. J Clin Periodontol 2003; 30(5):420-426.

[12] Ting M, Contreras A, Slots J. Herpesvirus in localized juvenile periodontitis. J Periodontal Res 2000; 35(1): 17-25.

[13] Slots J, and A. Contreras. Herpesviruses: a unifying causative factor in periodontitis? Oral Microbiol Immunol 2000 15(5):277-280

[14] Slots J, Sugar C, Kamma J J. Cytomegalovirus periodontal presence is associated with subgingival Dialister pneumosintes and alveolar bone loss. Oral Microbiol Immunol 2002.17(6):369-374
[15] Slots J, Kamma J. J, Sugar C. The herpesvirus-Porphyromonas gingivalis- periodontitis axis. J Periodontal Res 2003, 38(3):318-323.

[16] Saygun I, Kubar A, Ozdemir A, Yapar M, Slots J. Herpesviralbacterial interrelationships in aggressive periodontitis. J Periodontal Res 2004; 39(4):207-212.

[17] Watanabe SA, Correia-Silva Jde F, Horta MC, Costa JE, Gomez RS.EBV-1 and HCMV in aggressive periodontitis in Brazilian patients. Braz Oral Res 2007 21(4):336-41.

[18] Contreras A, Umeda M, Chen C, Bakker I, Morrison J L, Slots J. Relationship between herpesviruses and adult periodontitis and periodontopathic bacteria. J Periodontol 1999; 70(5):478-84.

[19] Rickinson E, Kieff E. Epstein Barr virus. In: Knipe DM, Howley PM, editors. Fields Viriology 4th ed. Philadelphia: Lippincott Williams and Wilkins; 2001; 2575-2627.

[20] Whitley RJ. Herpes simplex viruses. In: Fields BN, Knipe DM, Howley PM, editors. Fields Virology 3rd ed. Philadelphia: Lippincott - Raven Publishers 1996; 2297-342.

[21] Kubar A, Saygun I, Ozdemir A, Yapar M, Slots J. Real-time polymerase chain reaction quantification of human cytomegalovirus and Epstein-Barr virus in periodontal pockets and the adjacent gingiva of periodontitis lesions. J Periodontal Res 2005; 40(2):97-104.

[22] Ling LJ, Ho CC, Wu CY, Chen YT, Hung SL. Association between human herpesviruses and the severity of periodontitis. J Periodontol 2004; 75(11):1479-85.

[23] Saygun I, Sahin S, Ozdemir A, Kurtis B, Yapar M, Kubar A et al. Detection of human viruses in patients with chronic periodontitis and the relationship between viruses and clinical parameters. J Periodontol 2002; 73(12):1437-1443.

[24] Slots J, Saygun I, Sabeti M, Kubar A Epstein-Barr virus in oral diseases. J Periodontal Res 2006; 41: 235-244.

[25] Abramson SJ, Mills EL. Depression of neutrophil function by viruses and its role in secondary microbial infections. Rev Infect Dis 1988: 10: $326-341$.

[26] Saygun I, Kubar A, Ozdemir A, Slots J. Periodontitis lesions are a source of salivary cytomegalovirus and Epstein-Barr virus. J Periodontal Res 2005; 40(2):187-191.

[27] Yazdi KA, Sabeti M, Jabalameli F, Emaneini M, Kolahdouzan SA, Slots J. Relationship between human cytomegalovirus transcription and symptomatic apical periodontitis in Iran. Oral Microbiol Immunol 2008; 23(6):510-4.

[28] Kamma JJ, Contreras A, Slots J. Herpes viruses and periodontopathic bacteria in early-onset periodontitis. J Clin Periodontol 2001; 28(9):879-85.

[29] Ting M, Contreras A, Slots J. Herpesviruses in localized juvenile periodontitis. J Periodontal Res 2000; 35(1):17-25.

[30] Bilichodmath S, Mangalekar SB, Sharma DC, Prabhakar AK, Reddy SB, Kalburgi NB et al. Herpes viruses in chronic and aggressive periodontitis in an Indian sub-population.J Oral Sci 2009; 51(1):7986.

[31] Grenier G, Gagnon G, Grenier D. Detection of herpetic viruses in gingival crevicular

[32] fluid of patients suffering from periodontal diseases prevalence and effect of treatment. Oral Microbiol Immunol 2009; 24(6): 506-509.

[33] Dukic W, Bago I, Aurer A, Roguljic M. Clinical Effectiveness of Diode Laser Therapy as an Adjunct to Non-Surgical Periodontal Treatment: A Randomized Clinical Study. J Periodontal 2012; 10:146-153.

[34] Coluzzi D J. Fundamentals of dental lasers: science and instruments. Dent Clin N Am 48;2004; 751-770.

[35] Convissar RA. The biologic rationale for the use of lasers in dentistry Dent Clin N Am 48; 2004; 771-794.

[36] Watanabe SA, Correia-Silva Jde F, Horta MC, Costa JE, Gomez RS.EBV-1 and HCMV in aggressive periodontitis in Brazilian patients. Braz Oral Res 2007;21(4):336-41.

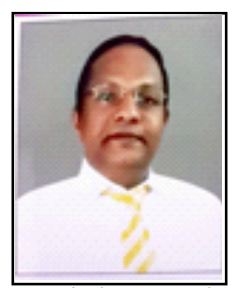

Prof. Dr. Krishna Kripal was born in Bangalore on 01/06/1969. He completed Bachelor of Dental surgery from College of Dental sciences, Mangalore and Masters of Dental Surgery in the Dept. of Periodontology from M R Ambedkar Dental College, Bangalore.

He was previously working as a READER in Hasanamba Dental College, Hassan. Currently he is a PROFESSOR in Rajarajeswari Dental College and Hospital, Bangalore. He has published several articles and books. Fundamentals and applications of laser dentistry; Sapna Ink; 2016, Integrated medicine and Periodontics, Scholars' Press, 2019

Prof. Dr. Kripal is a member of Indian Society of Periodontology and 
Indian Dental Association. 